\title{
3 \\ The Value Proposition of Trauma-Informed Care
}

We're all human, aren't we? Every human life is worth the same, and worth saving.

- J. K. Rowling, Harry Potter and the Deathly Hallows

\section{WHAT IS THE VALUE EQUATION?}

Total global healthcare expenditure is roughly $9 \%$ of the world's gross domestic product (GDP). GDP represents the total monetary, or market value, of all finished goods and services produced in a country and functions as a scorecard of a country's economic health. In 2018, the United States spent 16\% of its GDP on healthcare; twice as much as any other high-income country in the world (Figure 3.1; Tikkanen \& Abrams, 2020). Annually, \$935 billion of U.S. healthcare expenditure is spent on ineffective care that provides minimal benefit to the patient (Tikkanen \& Abrams, 2020). Moreover, Americans have the lowest life expectancy and the highest suicide rate across 36 high-income countries (Tikkanen \& Abrams, 2020). Premature birth survivors contribute to both the shortened life expectancy and the high suicide rate (Crump, 2020; Risnes et al., 2016).

Gestational age is inversely correlated with all causes of death between the ages of 0 and 45 years in men and women to include cardiovascular, respiratory, endocrine, neurological, cancer, and external causes (Crump, 2020). External causes, defined as accidents or violence, suicide, and substance abuse/overdoses, are responsible for the majority of deaths among preterm birth survivors (Risnes et al., 2016). Addressing the psychosocioemotional and spiritual needs of critically ill infants and their families requires an actionable prevention strategy that enriches the value of neonatal care by mitigating the long-term consequences associated with prematurity and NICU hospitalization (Lean, Rogers, Pail, \& Gerstein, 2018). 


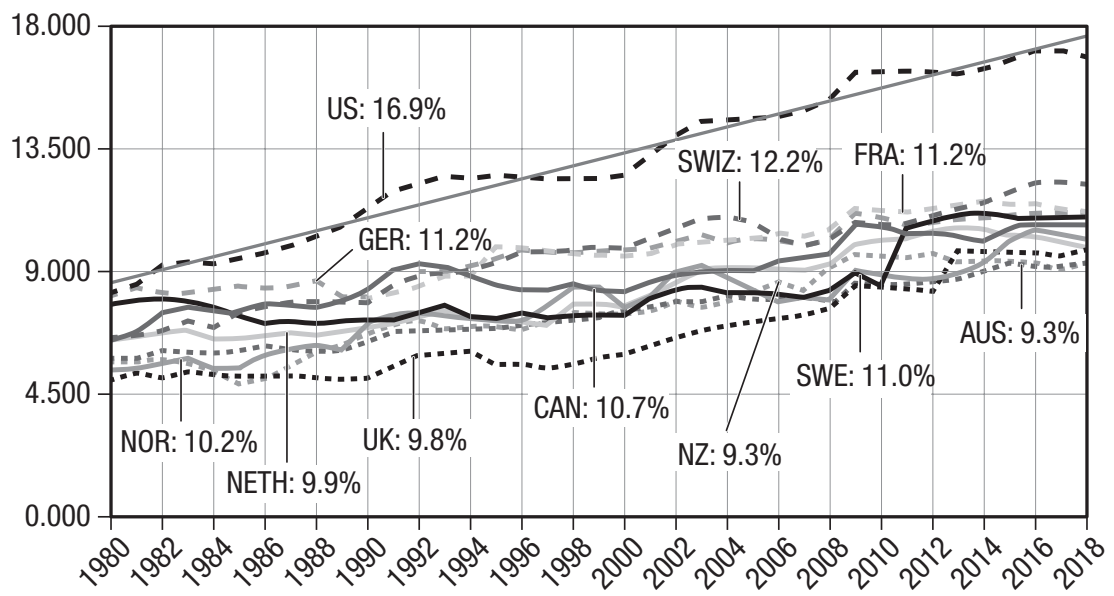

Figure 3.1 Healthcare spent as a percentage of gross domestic product adjusted for differences in cost of living 2018; Organization for Economic Co-operation and Development average $=8.8 \%$.

Source: Tikkanen, R., \& Abrams, M. K. (2020, January 30). U.S. health care from a global perspective, 2019: Higher spending, worse outcomes? https://www.commonwealthfund.org/publications/issue-briefs/2020/jan/us-health-care-global-perspective-2019

Value-based care shifts the paradigm from volume to value, with an emphasis on quality, safety, efficacy, and cost. The goal of a value-based healthcare system is to cocreate and measure outcomes meaningful for patients and their families with value expressed as the best health outcomes achieved per dollar spent (Marzorati \& Pravettoni, 2017). Value is an important feature of quality healthcare. However, a consensus on the meaning of value and what constitutes value in healthcare remains elusive for many key stakeholders (Table 3.1; Marzorati \& Pravettoni, 2017).

Dukhovny et al. (2016) introduced a value equation to examine the quality, efficacy, and safety of various interventions in neonatology juxtaposed to the costs, direct and indirect, associated with care delivery. The goal is to eradicate wasteful expenditure and ensure safe quality care:

$$
\text { Value }=\text { Outcomes } \div \text { Costs. }
$$

Waste refers to elements that incur costs but provide no benefit, such as duplicated services, poor care coordination, and so forth. Improving outcomes without increasing costs eradicates waste.

Improving outcomes almost always reduces costs in neonatology, both direct hospital costs and indirect costs such as lost productivity with regard to the infant's and/or family's present and future contributions to society (Dukhovny et al., 2016). Optimizing value doesn't need to be complicated, but does require a paradigm shift from "routine care" to value-based care and minimizing harm in the short term and long term (Profit et al., 2019). 
Table 3.1 Healthcare Stakeholders

\begin{tabular}{|l|l|}
\hline \multicolumn{1}{|l|}{ Stakeholder } & Value Attributes \\
\hline Clinicians & - Appropriateness of care \\
& - Effectiveness \\
& - Evidence-based \\
\hline Payers/hospital administrators & - Clinical benefit achieved for the money spent \\
& - Patient satisfaction \\
& - Reduced length of stay \\
\hline Policy makers & - Sustainability \\
& - Equanimity \\
\hline Patients & - Cost-effective \\
& - Satisfies health goals \\
& - Improved health-related quality of life \\
& - Respectful, transparent, and consistent communication \\
\hline
\end{tabular}

Source: Adapted from Marzorati, C., \& Pravettoni, G. (2017). Value is the key concept in the health care system: How it has influenced medical practice and clinical decision-making processes. Journal of Multidisciplinary Healthcare, 10, 101-106. doi: 10.2147/JMDH.S122383

Aligning evidence-based practice and evidence-based economics with quality- improvement processes creates the value road map that supports quality, safety, and efficacy for families in crisis (Dukhovny et al., 2016).

Value-conscious care begins with evidence-based practice. Despite the plethora of systematic reviews and meta-analyses highlighting the benefits and value of developmentally supportive, trauma-informed care for hospitalized infants and their families, translation into clinical practice remains troublesome. Bridging this gap requires an understanding of organizational culture and the knowledge, skills, and attitudes of clinicians toward evidence-based practice and cultural transformation.

Evidence-based economics suggest that economic phenomena, such as production, distribution, and consumption of goods and services, are not binary. Both direct and indirect costs contain many facets that must be understood to fully grasp their relationship to value. For example, the economic implications of pain management or two-person care may not be obvious, but that does not mean they do not bring value to the patient, family, and staff experience.

Quality improvement or the adoption of evidence-based best practices in the clinical setting brings the concept of value to life. Using the Plan-Do-Study-Act Model for Improvement, clinicians evaluate the effectiveness, quality, and safety of potentially better practices from a quantitative and qualitative perspective. Successful quality-improvement initiatives understand and address the social and behavioral components of change in order to establish accountability and sustainability, bringing value to the patient-family dyad, the clinician, and healthcare systems at large. 


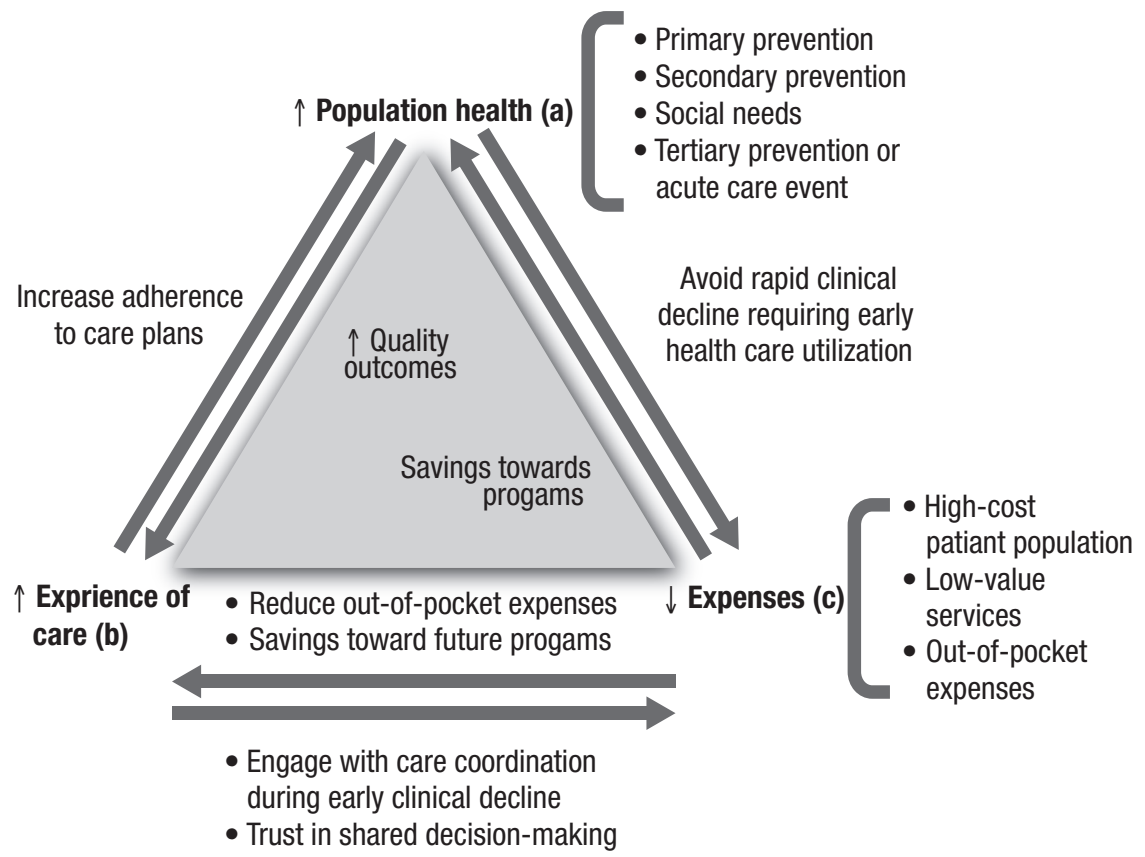

Figure 3.2 Triple Aim and its relationship among healthcare value components.

Source: Gupta, R. (2019). Health care value: Relationships between population health, patient experience and costs of care. Primary Care: Clinics in Office Practice, 46(4), 603-622. doi: 10.1016/j.pop.2019.07.005 Reprinted with permission from Elsevier.

\section{THE INSTITUTE FOR HEALTHCARE IMPROVEMENT'S TRIPLE AIM}

The Institute for Healthcare Improvement's (IHI) Triple Aim is a unique framework developed to optimize health system performance through (a) the pursuit of improved population health, and (b) experience of care (c) while reducing costs (Figure 3.2). Population health refers to the quality of health for a specific population that includes both healthcare and the social determinants of health (SDOH; Gupta, 2019). Quality of healthcare is defined by its safety, patient-centeredness, effectiveness, timeliness, and equity.

SDOH include health and healthcare, neighborhoods and the built environment, economic stability, education, and social and community context. These determinants take on new meaning within the context of the NICU and influence lifelong health and wellness for this fragile and vulnerable population (Table 3.2). Where you live affects your health and well-being. For the NICU population, living in the NICU environment for days, weeks, and months, influences the developmental trajectory of the infant-family dyad in meaningful and measurable ways across the life span.

Since the introduction of the IHI's Triple Aim in 2008, there has been some criticism that the framework fails to explicitly acknowledge the critical role of the clinical 


\section{Table 3.2 Social Determinants of Health Within the NICU Context}

\begin{tabular}{|c|c|}
\hline SDOH & NICU Context \\
\hline Health and healthcare & $\begin{array}{l}\text { - Medical practices and NICU-related quality } \\
\text { of care to include (but not be limited to) pain- } \\
\text { management practices, sleep protection, diet, } \\
\text { postural support, skin care, etc. }\end{array}$ \\
\hline Neighborhood and built environment & $\begin{array}{l}\text { - Physical environment of the NICU to include (but } \\
\text { not be limited to) sensory, spacial, and aesthetic } \\
\text { dimensions; urban versus rural setting; academic } \\
\text { versus private-practice models of care delivery; } \\
\text { etc. }\end{array}$ \\
\hline Economic stability & $\begin{array}{l}\text { - Economics of the facility influencing staffing } \\
\text { patterns and resources } \\
\text { - Family economics, i.e., food and/or housing } \\
\text { insecurity, transportation and parking, childcare } \\
\text { resources, health insurance, etc. }\end{array}$ \\
\hline Education & $\begin{array}{l}\text { - Organizational investment in continuous } \\
\text { professional development for staff } \\
\text { - Individual clinician investment in ongoing } \\
\text { professional education } \\
\text { - Parent knowledge/education regarding parenting } \\
\text { skills, breastfeeding benefits, skin-to-skin care, } \\
\text { importance of parental presence and emotional } \\
\text { closeness, etc. }\end{array}$ \\
\hline Social and community context & $\begin{array}{l}\text { - Organizational catchment area and commitment } \\
\text { to meeting the unique needs of demographics } \\
\text { served; organizational culture and leadership } \\
\text { model } \\
\text { - Clinicians' knowledge, skills and attitudes } \\
\text { regarding caring encounters with infants and } \\
\text { families; reading infant behavioral cues to provide } \\
\text { responsive contingent care } \\
\text { - Family culture; social support network and } \\
\text { resources; trauma-history; knowledge, skills, and } \\
\text { attitudes about parenting their hospitalized infant }\end{array}$ \\
\hline
\end{tabular}

SDOH, social determinants of health.

workforce in achieving healthcare transformation (Sikka et al., 2015). The IHI introduced a framework for "joy in work" in 2017 in response to escalating rates of clinician burnout. Finding purpose and joy in work are crucial for the physical, psychological, and emotional health and well-being of healthcare professionals (Galuska et al., 2018; Sikka et al., 2015). Experts recommend expanding the IHI's Triple Aim framework to include "joy in work" —a 


\section{EXHIBIT 3.1 QUADRUPLE AIM WITH RECIPROCAL DOMAINS OF CLINICIAN WELL-BEING}

\begin{tabular}{|l|l|l|}
\hline \\
$\begin{array}{l}\text { Enhance patient } \\
\text { Experience }\end{array}$
\end{tabular}

EHR, electronic health record.

Source: Anandarajah, A. P., Quill, T. E., \& Privitera, M. R. (2018). Adopting the Quadruple Aim: The University of Rochester Medical Center experience: Moving from physician burnout to physician resilience. American Fournal of Medicine, 131(8), 979-986. doi: 10.1016/j .amjmed.2018.04.034 Reprinted with permission from Elsevier.

Quadruple Aim (Anandarajah et al., 2018; Galuska et al., 2018; Sikka et al., 2015). Adding this fourth element enhances teamwork, improves efficiencies, results in high-quality patient care, and greatly improves job satisfaction (Exhibit 3.1).

The concept of population health and experience of care underpins the core measures for trauma-informed care in the NICU (Figure 3.3). The core measures are diseaseindependent domains that address the human needs of the patient and family (refer to chapters in Section II). These measures emphasize prevention and protection as turnkey for safe, quality healthcare and lifelong health and wellness. Preventive and protective 


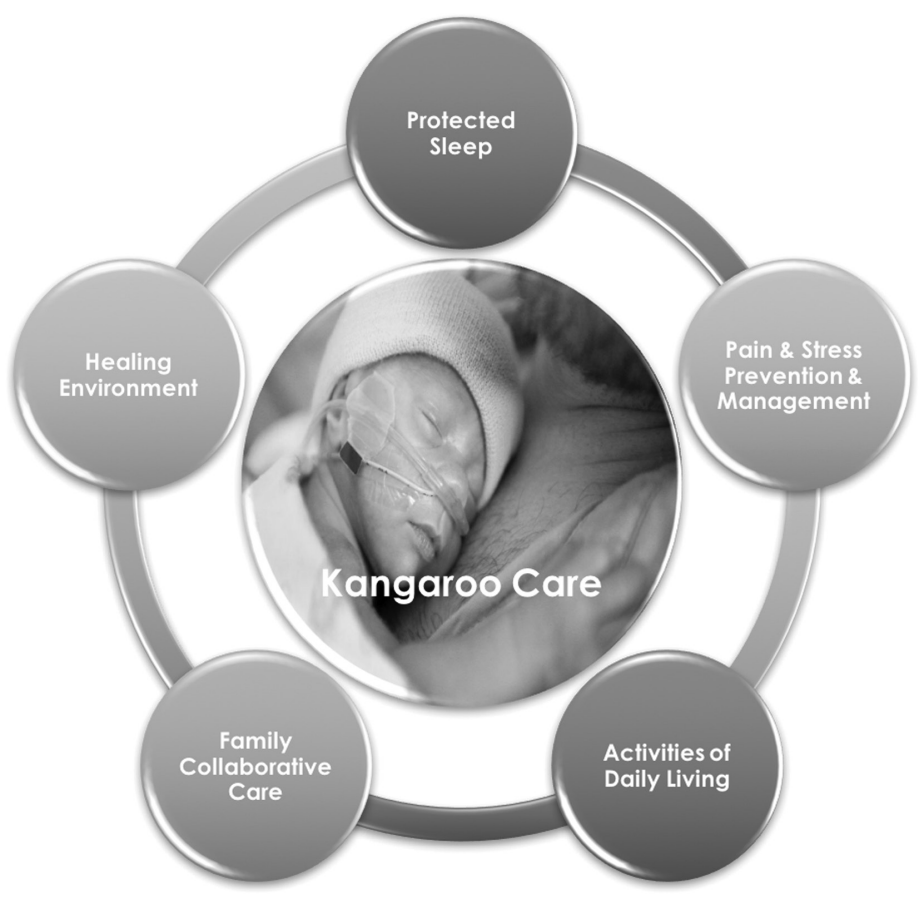

Figure 3.3 Core measures for trauma-informed care. Kangaroo care, or skin-to-skin care, is the quintessential care practice impacting each core measure.

Source: Reprinted with permission from Caring Essentials Collaborative, LLC.

healthcare practices that mitigate and minimize toxic stress reduce morbidity, increase value, and enrich the individual's quality of life.

Attending to an infant's basic needs as a developing human being is a primary prevention strategy in the hospital setting. Intensive care and primary preventive care do not need to be mutually exclusive in the NICU. Through experience-dependent and experience-expectant neural activity, newborns and infants learn about their world and their value in the world. All mammals, including humans, have a biological imperative for social connectedness (Sanders \& Hall, 2018). This biologic realty must be prima facie for all hospitalized newborns and infants to ensure the highest standard for population health.

\section{REDUCING THE GLOBAL BURDEN OF PRETERM BIRTH AND NEONATAL COMPLICATIONS}

Approximately 15 million infants are born prematurely around the globe. Prematurity is the leading cause of death in children under the age of 5 years. In low-income countries, half of infants born at less than 32 weeks' gestation die due to a lack of appropriate cost-effective 
Table 3.3 Minor Morbidities

- Minor cognitive deficits

- Learning disabilities

- Executive dysfunction

- Motor delays

- Visual motor perceptual difficulties

- Attention deficit disorders

- Language delays
- Behavioral problems

- Cortical vision impairment

- Depression

- Anxiety

- Social difficulties

- Auditory dys-synchrony

- Autism spectrum

care such as warmth, breastfeeding resources, and basic care capabilities to manage infections and respiratory conditions. Infants born in high-income countries generally survive but with an increased burden of disability and morbidity.

Wide variation in severe neonatal morbidity is reported globally despite a decline in neonatal mortality across all gestational ages (Bonamy et al., 2019; Liu et al., 2019). Major morbidity in NICU survivors includes intraventricular hemorrhage, periventricular leukomalacia, necrotizing enterocolitis, bronchopulmonary dysplasia, and sepsis (Anderson et al., 2016). Major morbidities have a disabling impact on the survivor; however, for those who escape major morbidity, many are diagnosed with minor morbidities (Table 3.3). A spectrum of outcome possibilities is observed within each minor morbidity category. It is rare for an individual to experience an isolated minor morbidity; clusters of conditions are more common. These clustered conditions impact the affected individual and family physically, socially, emotionally, cognitively, and psychologically.

Reducing the burden of these minor morbidities and possibly influencing the evolution of many of the major morbidities mediated by inflammation requires attention to managing the infants experience of toxic stress and pain (Kuhlman et al., 2020; Patra et al., 2017; Weber \& Harrison, 2019). High circulating levels of inflammatory mediators are linked to increased risk of many adult diseases (David et al., 2017; Kuhlman et al., 2020). Epidemiological and epigenetic studies reveal early-life adversity, such as preterm birth and other perinatal conditions, interact with the epigenome and microbiome altering developmental programming (refer to Chapter 4; Fumagalli et al., 2018; Lu \& Claud, 2019; Montirosso et al., 2016; Provenzi et al., 2017, 2018). Early prevention and optimal nutrition are effective interventions to preserve long-term health and wellness (Simeoni et al., 2018).

Buffering early-life toxic stress reduces the burden of disease associated with the NICU experience (Weber \& Harrison, 2019). Parental presence must be actively pursued and supported by healthcare organizations. Creating welcoming, comfortable, and suitable accommodations for parents and families of hospitalized newborns is a first step in preserving the integrity of the family in crisis and buffer the toxic stress experience of the infant (refer to Chapter 7). Parental presence and parental holding are related to improved neurodevelopmental outcomes in preterm infants through ages 4 to 5 years (Pineda et al., 2018; Reynolds et al., 2013). 
The buffering effect of maternal presence is operationalized through skin-to-skin care and breastfeeding experiences. In addition to improved neurodevelopmental outcomes, skin-to-skin care and breastfeeding results in significant cost savings (Lowson et al., 2015; Stuebe et al., 2017). Skin-to-skin care and breastfeeding are associated with a reduced length of hospital stay and a decrease in subsequent re-hospitalizations resulting in cost savings in excess of nearly $\$ 905,000$ (Lowson et al., 2015). Stuebe et al. (2017) reported a $5 \%$ increase in breastfeeding rates statistically significantly reduced the incidence of infectious morbidity over the first year of life using a simulation model with staggering medical cost savings.

\section{THE VALUE PROPOSITION OF TRAUMA-INFORMED CARE IN THE NICU}

The degree to which every aspect of the NICU experience prompts a stress response is the degree to which the value of service can be improved by mitigating and managing traumatic stress. Chronic early-life stress is associated with lifelong increased risk for psychopathology and chronic health problems mediated by dysregulation of the hypothalamic-pituitary-adrenal (HPA) axis (refer to Chapter 4; Bunea et al., 2017). Dysregulation of the HPA axis is linked to asthma, chronic pain syndromes, impaired cognitive and emotional capacity, depression, anxiety, as well as social and behavioral difficulties (Agorastos et al., 2018; Burke et al., 2017; Chen \& Baram, 2016; Rosa et al., 2018).

Nurses have the power to shape the care environment and care experience for hospitalized infants and their families (Weber et al., 2018). Supporting activation of the oxytocin (OT) system disarms the stress response, cultivates social connectedness, and is a necessary and critical component for optimal neurodevelopment of all infants (Figure 3.4; Weber et al., 2018). Facilitating caring encounters that activate the OT system, such as skin-to-skin care, breastfeeding, social vocalizations, holding, and positive touch, become therapeutic strategies creating a socially supportive milieu for the infant and family in crisis (Scatliffe et al., 2019; Weber et al., 2018). Weber et al. (2018) present examples of nursing diagnosis and potential nursing interventions that mediate OT activity (Table 3.4)

Toxic stress is a mediator between early-life adversity and suboptimal outcomes in learning, behavior, and health. Social supportive and nurturing interactions counteract the stress response and cultivate connectedness and resilience. Understanding the biology underlying early-life stress and social, nurturing interactions opens up new opportunities for primary prevention and earlier intervention for infants and families in the NICU and beyond.

Adhering to the admonishment "first, do no harm," the value proposition of traumainformed care is clear. Changing the routine care paradigm to a trauma-informed approach requires a cultural shift that recognizes the importance and value of compassionate, personcentered, family-collaborative care. Many healthcare professionals are unfamiliar with the 


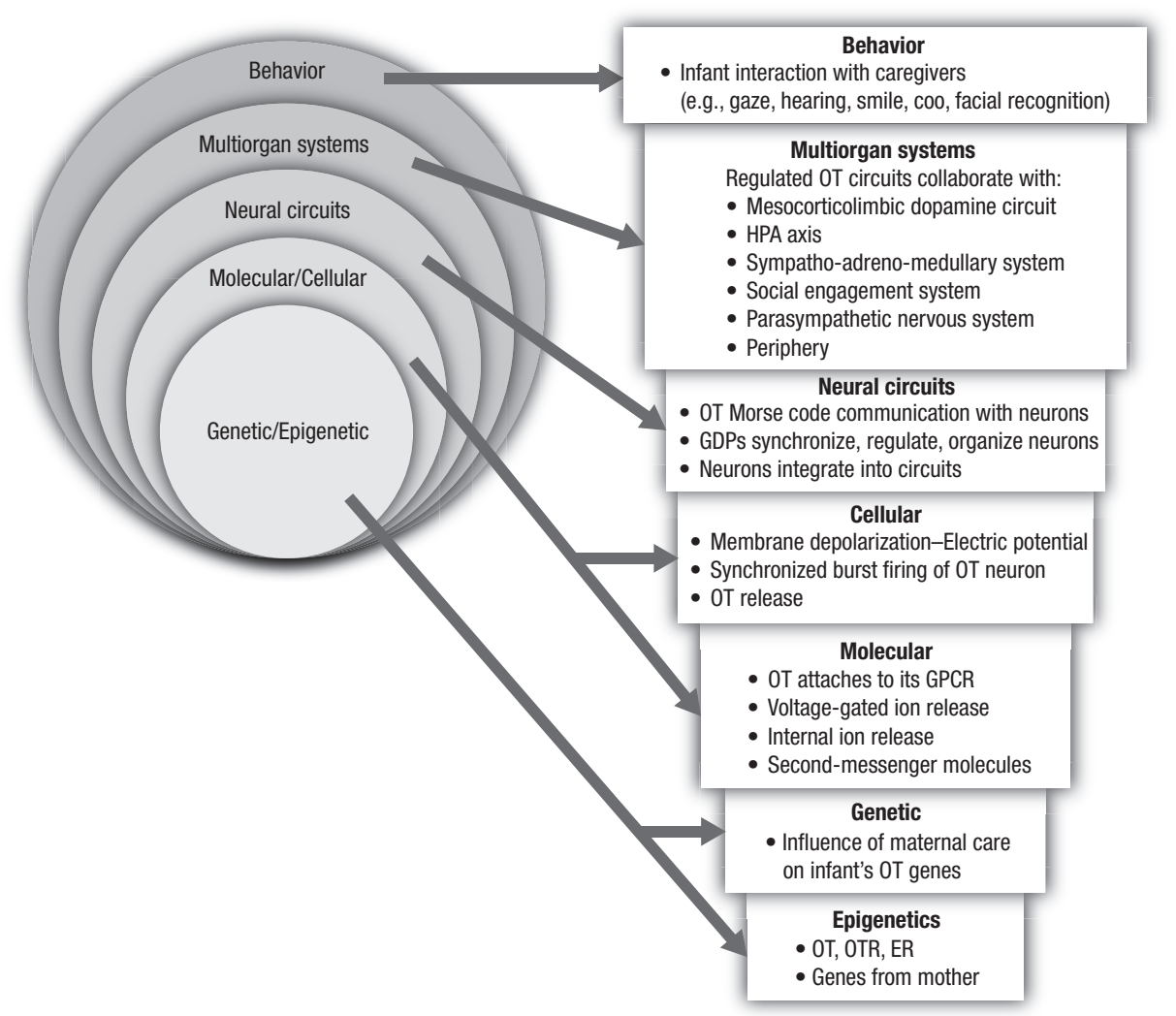

Figure 3.4 Nested hierarchies of effects of oxytocin.

ER, estrogen receptors; GDP, giant depolarizing potentials; GPCR, G-protein-coupled receptors; HPA, hypothalamic-pituitary-adrenal; OT, oxytocin; OTR, oxytocin receptors.

Source: Weber, A. M., Harrison, T. M., \& Steward, D. K. (2018). Expanding regulation theory with oxytocin: A psychoneurobiological model for infant development. Nursing Research, 67(2), 133-145. doi: 10.1097/NNR.0000000000000261 Reprinted with permission from Wolters Kluwer Health, Inc.

concept of trauma-informed care. Engaging subject matter experts in trauma-informed cultural transformation (Caring Essentials Collaborative, LLC, is the definitive resource for trauma-informed education and cultural transformation for organizations serving newborns and infants) will support your organization's journey to deliver value-conscious care in the NICU.

\section{SUMMARY}

Given what is now known about the biological implications of early-life adversity and traumatic stress in the NICU (refer to Chapter 2and Chapter 4), there are clear opportunities to eliminate waste, improve outcomes, and reduce costs through the adoption of a trauma-informed 


\section{Table 3.4 Nursing Diagnoses and Interventions Related to Oxytocin Processes}

\begin{tabular}{|c|c|c|}
\hline Focus & $\begin{array}{l}\text { Nursing Diagnosis/Nursing } \\
\text { Interventions }\end{array}$ & Underlying OT-Based Process \\
\hline Infant & $\begin{array}{l}\text { Pain: Chronic/acute } \\
\text { - Assess pain using developmentally } \\
\text { appropriate tools. } \\
\text { - Use nonpharmacologic interventions to } \\
\text { reduce pain (e.g., nonnutritive sucking, } \\
\text { breastfeeding, kangaroo care, facilitated } \\
\text { tucking). }\end{array}$ & $\begin{array}{l}\text { - OT nerves in spine } \\
\text { andperipheral nervous system } \\
\text { regulate pain. } \\
\text { - OT reduces pain thresholds, } \\
\text { pain perception. }\end{array}$ \\
\hline Infant & $\begin{array}{l}\text { Disorganized behavior } \\
\text { - Use consistent nurturing response. } \\
\text { - Assist parents; modify environment for } \\
\text { appropriate stimulation (e.g., lighting, } \\
\text { sound). } \\
\text { - Model caregiving: Support infant } \\
\text { behavioral organization (e.g., hand } \\
\text { containment, facilitated tucking, } \\
\text { nonnutritive sucking). }\end{array}$ & $\begin{array}{l}\text { - Physical contact increases OT } \\
\text { release. } \\
\text { - Infant sleep, arousal, and hunger } \\
\text { regulate the OT system. } \\
\text { - Regulation of basic infant } \\
\text { behaviors is the cornerstone for } \\
\text { supportive social interaction. }\end{array}$ \\
\hline Infant & $\begin{array}{l}\text { Delayed development: Risk } \\
\text { - Assess risk factors (e.g., prematurity, } \\
\text { genetic disorders). } \\
\text { - Identify/use educational resources to } \\
\text { facilitate infant development. } \\
\text { - Implement neuroprotective interventions } \\
\text { (e.g., kangaroo care, breastfeeding, } \\
\text { stress reduction, modification of } \\
\text { environmental stimuli, minimize parent- } \\
\text { infant separation). }\end{array}$ & $\begin{array}{l}\text { - OT is necessary for } \\
\text { neurodevelopmental processes. } \\
\text { - We hypothesize that } \\
\text { neuroprotective nursing } \\
\text { interventions facilitate OT-based } \\
\text { neurobiological processes in the } \\
\text { infant. }\end{array}$ \\
\hline Mother & $\begin{array}{l}\text { Anxiety } \\
\text { - Assess level of and physical reactions to } \\
\text { anxiety (heart racing, sleeplessness). } \\
\text { - Encourage positive self-talk (e.g., "I can } \\
\text { do this one step at a time"). } \\
\text { - Use empathy to validate feelings. } \\
\text { - Minimize the number of professionals } \\
\text { - } \text { with whom the parents have contact. } \\
\text { increases parental anxiety). } \\
\text { - Provide anticipatory guidance on infant } \\
\text { care plan. }\end{array}$ & $\begin{array}{l}\text { - Divergent effects of OT in stress } \\
\text { response systems produce } \\
\text { engagement or avoidance/ } \\
\text { aggression with appropriate } \\
\text { anxiety responses to stress. } \\
\text { - OT decreases social anxiety } \\
\text { to facilitate socially based } \\
\text { behaviors during maternal-infant } \\
\text { interaction. }\end{array}$ \\
\hline
\end{tabular}


Table 3.4 Nursing Diagnoses and Interventions Related to Oxytocin Processes (continued)

\begin{tabular}{|c|c|c|}
\hline Focus & $\begin{array}{l}\text { Nursing Diagnosis/Nursing } \\
\text { Interventions }\end{array}$ & Underlying OT-Based Process \\
\hline Mother & $\begin{array}{l}\text { Powerlessness: Risk } \\
\text { - Assess parental satisfaction with the } \\
\text { infant's care. } \\
\text { - Encourage parents to participate in } \\
\text { family-centered rounds. } \\
\text { - Assist parents in making decisions } \\
\text { regarding infant treatment schedule. } \\
\text { - Encourage parents to fully participate in } \\
\text { the infant's care. } \\
\text { - Establish a routine for daily phone calls; } \\
\text { initiate calls. } \\
\text { - Provide a sense of control by having } \\
\text { parents plan infant care/activities. }\end{array}$ & $\begin{array}{l}\text { - Mothers are at risk for alteration } \\
\text { in parental role, ineffective } \\
\text { parental performance, impaired } \\
\text { parent-infant interaction, } \\
\text { and impaired maternal-infant } \\
\text { attachment when they do not } \\
\text { feel valuable and in control of } \\
\text { infant care, which we theorize } \\
\text { results in dysregulation of the } \\
\text { maternal OT system. }\end{array}$ \\
\hline Mother & $\begin{array}{l}\text { Role strain: Parent/caregiver } \\
\text { - Provide a consistent, encouraging, } \\
\text { - } \text { nonjudgmental environment. } \\
\text { can successfully achieve. } \\
\text { - Provide a "homelike" environment (e.g., } \\
\text { family personalizes infant room/space). } \\
\text { - Provide positive feedback for supportive } \\
\text { parenting behaviors. }\end{array}$ & $\begin{array}{l}\text { Empowering mothers to own } \\
\text { their parental role results in } \\
\text { sensitive parenting behaviors, } \\
\text { higher levels of OT in mother } \\
\text { and infant, and greater brain } \\
\text { activation and connectivity in } \\
\text { OT-based networks. }\end{array}$ \\
\hline Mother & $\begin{array}{l}\text { Parental performance: Ineffective } \\
\text { - Use active listening: Explore } \\
\text { understanding of developmental needs, } \\
\text { expectations. } \\
\text { - Examine parenting style, behaviors (e.g., } \\
\text { psychosocial environment at home, } \\
\text { attribution of negative traits to infant, } \\
\text { involvement with infant care). } \\
\text { - Assess maternal depression, stress, } \\
\text { and anxiety. } \\
\text { - Plan education directed toward parental } \\
\text { concerns. } \\
\text { - Model developmentally appropriate } \\
\text { caregiving skills (e.g., gentle touch, soft } \\
\text { voice, containment, nonnutritive sucking, } \\
\text { contingent responses to infant cues). }\end{array}$ & $\begin{array}{l}\text { - Maternal OT is associated with } \\
\text { supportive maternal behaviors } \\
\text { and coordination of social } \\
\text { interactions with the neonate's } \\
\text { alert state. } \\
\text { - Parenting behaviors that release } \\
\text { infant OT include comforting } \\
\text { touch, soft voice, gaze, } \\
\text { contingent responses, high } \\
\text { quality affect. } \\
\text { - Parents who display more } \\
\text { affectionate touch increase their } \\
\text { OT levels after interaction with } \\
\text { their infant. }\end{array}$ \\
\hline
\end{tabular}


Table 3.4 Nursing Diagnoses and Interventions Related to Oxytocin Processes (continued)

\begin{tabular}{|c|c|c|}
\hline Focus & $\begin{array}{l}\text { Nursing Diagnosis/Nursing } \\
\text { Interventions }\end{array}$ & Underlying OT-Based Process \\
\hline & $\begin{array}{l}\text { - Acknowledge, praise parenting } \\
\text { strengths. } \\
\text { - Initiate referrals to agencies (e.g., Help } \\
\text { me Grow, March of Dimes), parent } \\
\text { education programs, social support } \\
\text { groups (e.g., NICU Peer Parent Support } \\
\text { groups). }\end{array}$ & \\
\hline Dyad & $\begin{array}{l}\text { Breastfeeding: Ineffective } \\
\text { - Provide lactation counseling and } \\
\text { breastfeeding assistance. } \\
\text { - Provide parent education. } \\
\text { - Infant engaging in nonnutritive sucking } \\
\text { at breast. }\end{array}$ & $\begin{array}{l}\text { - OT levels are higher in } \\
\text { breastfeeding mothers than in } \\
\text { formula-feeding mothers. } \\
\text { - Human milk OT levels are higher } \\
\text { after breastfeeding. }\end{array}$ \\
\hline Dyad & $\begin{array}{l}\text { Family processes: Interrupted } \\
\text { - Assist parents in identifying and } \\
\text { prioritizing family strengths and needs. } \\
\text { - } \text { Promote positive attitudes by } \\
\text { communicating what skills parents } \\
\text { already do well. } \\
\text { - Help parents identify appropriate } \\
\text { support systems (e.g., extended family, } \\
\text { friends, social worker) and community } \\
\text { resources (e.g., faith groups, volunteers, } \\
\text { respite care). } \\
\text { - Identify social services (e.g., } \\
\text { transportation, finances). }\end{array}$ & $\begin{array}{l}\text { - Ensuring that family's needs are } \\
\text { met relieves parental anxiety, } \\
\text { allows parents to maximize time } \\
\text { in the NICU. } \\
\text { - When family processes are } \\
\text { restored, parents are less } \\
\text { stressed, more likely to engage } \\
\text { in supportive social interactions } \\
\text { with their infants, which cause } \\
\text { release of OT. }\end{array}$ \\
\hline Dyad & $\begin{array}{l}\text { Parent-infant interaction: Impaired } \\
\text { - Assess parent-infant interactions, } \\
\text { especially during feeding and care. } \\
\text { - Model consistent, nurturing behaviors } \\
\text { when caring for and interacting with } \\
\text { infant. } \\
\text { - Foster developmentally supportive } \\
\text { parenting behaviors. }\end{array}$ & $\begin{array}{l}\text { Early, consistent, } \\
\text { developmentally supportive } \\
\text { interactions regulate infant OT } \\
\text { brain biology, emotions, and } \\
\text { social behaviors that emerge } \\
\text { from that biology. }\end{array}$ \\
\hline
\end{tabular}


Table 3.4 Nursing Diagnoses and Interventions Related to Oxytocin Processes (continued)

\begin{tabular}{|c|c|c|}
\hline Focus & $\begin{array}{l}\text { Nursing Diagnosis/Nursing } \\
\text { Interventions }\end{array}$ & Underlying OT-Based Process \\
\hline Dyad & $\begin{array}{l}\text { Maternal-infant attachment impaired: } \\
\text { Risk } \\
\text { - Minimize parent-infant separation } \\
\text { immediately after birth. } \\
\text { - Identify infant's strengths and } \\
\text { vulnerabilities. } \\
\text { - Educate parents regarding infant } \\
\text { growth and development, clarifying } \\
\text { expectations. } \\
\text { - Invite parents to spend the night (e.g., } \\
\text { Ronald McDonald House, hospital } \\
\text { room). } \\
\text { - Provide infant photos, mementos } \\
\text { (e.g., outgrown blood pressure cuff, } \\
\text { hat), journal developmental milestone } \\
\text { reports to celebrate progress, promote } \\
\text { normalcy. } \\
\text { - Suggest parents provide a photo and/or } \\
\text { audiotape of themselves. }\end{array}$ & $\begin{array}{l}\text { - Synchronized, supportive } \\
\text { interactions foster attachment, } \\
\text { which is facilitated by the OT } \\
\text { system. } \\
\text { - OT coordinates with the social } \\
\text { engagement system, which } \\
\text { produces the physiologic states, } \\
\text { emotions, and engagement } \\
\text { cues that encourage dyadic } \\
\text { attachment. }\end{array}$ \\
\hline
\end{tabular}

\section{OT, oxytocin.}

Source: Weber, A. M., Harrison, T. M., \& Steward, D. K. (2018). Expanding regulation theory with oxytocin: A psychoneurobiological model for infant development. Nursing Research, 67(2), 133-145. doi: 10.1097/NNR.0000000000000261 Reprinted with permission from Wolters Kluwer Health, Inc.

paradigm. A trauma-informed approach in the NICU promotes a sense of safety, security, and connectedness while cultivating resilience for infants and families in crisis with far-reaching implications for health and well-being (Coughlin, 2017; Crump, 2020; Sanders \& Hall, 2018). The value trauma-informed care confers on infants, families, and clinicians is priceless.

It is an absolute buman certainty that no one can know his own beauty or perceive a sense of his own worth until it has been reflected back to bim in the mirror of another loving, caring human being. -John Joseph Powell

\section{READER RESOURCES}

Brain hero: www.youtube.com/watch?v=s31HdBeBgg4

Triple Aim: www.youtube.com/watch?time_continue=89\&v=a_QskzKFZnI\&feature=emb_logo 


\section{REFERENCES}

Agorastos, A., Pervanidou, P., Chrousos, G. P., \& Kolaitis, G. (2018). Early life stress and trauma: Developmental neuroendocrine aspects of prolonged stress system dysregulation. Hormones, 17, 507-520. https://doi.org/10.1007/s42000-018-0065-x

Anandarajah, A. P., Quill, T. E., \& Privitera, M. R. (2018). Adopting the quadruple aim: The University of Rochester Medical Center experience: Moving from physician burnout to physician resilience. American fournal of Medicine, 131(8), 979-986. https://doi.org/10.1016/j .amjmed.2018.04.034

Anderson, J. G., Baer, R. J., Partridge, J. C., Kuppermann, M., Franck, L. S., Rand, L., JelliffePawlowski, L. L., \& Rogers, E. E. (2016). Survival and major morbidity of extremely preterm infants: A population-based study. Pediatrics, 138(1), e20154434. https://doi.org/10.1542/ peds.2015-4434

Bonamy, A. K. E., Zeitlin, J., Piedvache, A., Maier, R. F., van Heijst, A., Varendi, H., Manktelow, B. N., Fenton, A., Mazela, J., Cuttini, M., Norman, M., Petrou, S., van Reempts, P., Barros, H., \& Draper, E. S. (2019). Wide variation in severe neonatal morbidity among very preterm infants in European regions. Archives of Disease in Childhood-Fetal and Neonatal Editions, 104(1), F36-F45. https://doi.org/10.1136/archdischild-2017-313697

Bunea, I. M., Szentagotai-Tatar, A., \& Miu, A. C. (2017). Early-life adversity and cortisol response to social stress: A meta-analysis. Translational Psychiatry, 7, 1274. https://doi.org/10.1038/ s41398-017-0032-3

Burke, N. N., Finn, D. P., McGuire, B. E., \& Roche, M. (2017). Psychological stress in early life as a predisposing factor for the development of chronic pain: Clinical and preclinical evidence and neurobiological mechanisms. Fournal of Neuroscience Research, 95(6), 1257-1270. https:// doi.org/10.1002/jnr.23802

Chen, Y., \& Baram, T. Z. (2016). Toward understanding how early-life stress reprograms cognitive and emotional brain networks. Neuropsychopharmacology, 41(1), 197-206. https://doi.org/10.1038/ npp.2015.181

Coughlin, M. (2017). Trauma-informed, neuroprotective care for hospitalized newborns and infants. Infant, 13(5), 176-179.

Crump, C. (2020). Preterm birth and mortality in adulthood: A systematic review. Fournal of Perinatology, 40(6), 833-843. https://doi.org/10.1038/s41372-019-0563-y

David, J., Measelle, J., Ostlund, B., \& Ablow, J. (2017). Association between early life adversity and inflammation during infancy. Developmental Psychobiology, 59(6), 696-702. https://doi.org/10.1002/ dev. 21538

Dukhovny, D., Pursley, D. M., Kirpalani, H. M., Horbar, J. H., \& Zupancic, J. A. F. (2016). Evidence, quality, and waste: Solving the value equation in neonatology. Pediatrics, 137(3), e20150312. https://doi.org/10.1542/peds.2015-0312

Fumagalli, M., Provenzi, L., De Carli, P., Dessimone, F., Sirgiovanni, I., Giorda, R., Cinnante, C., Squarcina, L., Pozzoli, U., Triulzi, F., Brambilla, P., Borgatti, R., Mosca, F., \& Montirosso, R. (2018). From early stress to 12 -month development in very preterm infants: Preliminary findings on epigenetic mechanisms and brain growth. PLoS One, 13(1), e0190602. https://doi .org/10.1371/journal.pone.0190602

Galuska, L., Hahn, J., Polifroni, E. C., \& Crow, G. (2018). A narrative analysis of nurses' experiences with meaning and joy in nursing practice. Nursing Administration Quarterly, 42(2), 154-163. https://doi.org/10.1097/NAQ.0000000000000280 
Gupta, R. (2019). Health care value: Relationships between population health, patient experience and costs of care. Primary Care: Clinics in Office Practice, 46(4), 603-622. https://doi.org/10.1016/j .pop.2019.07.005

Kuhlman, K. R., Horn, S. R., Chiang, J. J., \& Bower, J. E. (2020). Early life adversity exposure and circulating markers of inflammation in children and adolescents: A systematic review and metaanalysis. Brain, Behavior, and Immunity, 86, 30-42. https://doi.org/10.1016/j.bbi.2019.04.028

Lean, R. E., Rogers, C. E., Pail, R. A., \& Gerstein, E. D. (2018). NICU hospitalization: Longterm implications on parenting and child behaviors. Current Treatment Options in Pediatrics, 4(1), 49-69.

Lowson, K., Offer, C., Watson, J., McGuire, B., \& Renfrew, M. J. (2015). The economic benefits of increasing kangaroo skin-to-skin care and breastfeeding in neonatal units: Analysis of a pragmatic intervention in clinical practice. International Breastfeeding Fournal. 10, 11. https://doi .org/10.1186/s13006-015-0035-8

Lu, J., \& Claud, E. C. (2019). Connection between gut microbiome and brain development on preterm infants. Developmental Psychobiology, 61(5), 739-751. https://doi.org/10.1002/dev.21806

Lui, K., Lee, S. K., Kusuda, S., Adams, M., Vento, M., Reichman, B., Darlow, B. A., Lehtonen, L., Modi, N., Norman, M., Hakansson, S., Bassler, D., Rusconi, F., Lodha, A., Yang, J., Shah, P. S.; on behalf of the International Network for Evaluation of Outcomes (iNeo) of neonates investigators. (2019). Trends in outcomes for neonates born very preterm and very low birth weight in 11 high-income countries. Fournal of Pediatrics, 215, 32-40. https://doi.org/10.1016/j .jpeds.2019.08.020

Marzorati, C., \& Pravettoni, G. (2017). Value is the key concept in the health care system: How it has influenced medical practice and clinical decision-making processes. Fournal of Multidisciplinary Healthcare, 10, 101-106. https://doi.org/10.2147/JMDH.S122383

Montirosso, R., Provenzi, L., Fumagalli, M., Sirgiovanni, Giorda, R., Pozzoli, U., Beri, S., Menozzi, G., Tronick, E., Morandi, F., Mosca, F., \& Borgatti, R. (2016). Serotonin transporter gene (SLC6A4) methylation associates with neonatal intensive care unit stay and 3-month-old temperament in preterm infants. Child Development, 87(1), 38-48. https://doi.org/10.1111/cdev.12492

Patra, A., Huang, H., Bauer, J. A., \& Giannone, P. J. (2017). Neurological consequences of systemic inflammation in the premature neonate. Neural Regeneration Research, 12(6), 890-896. https:// doi.org/10.4103/1673-5374.208547

Pineda, R., Bender, J., Hall, B., Shabosky, L., Annecca, A., \& Smith, J. (2018). Parent participation in the neonatal intensive care unit: Predictors and relationships to neurobehavior and developmental outcomes. Early Human Development, 117, 32-38. https://doi.org/10.1016/j .earlhumdev.2017.12.008

Profit,J., Scheid,A., \& Ridout, E. (2019, October 30). First, do no harm:Value-driven patient safety in the neonatal intensive care unit. https://psnet.ahrq.gov/perspective/first-do-no-harm-value-driven-patient-safetyneonatal-intensive-care-unit

Provenzi, L., Fumagalli, M., Giorda, R., Morandi, F., Sirgiovanni, I., Pozzoli, U., Mosca, F., Borgatti, R., \& Montirosso, R. (2017). Maternal sensitivity buffers the association between SLC6A4 methylation and socio-emotional stress response in 3-mont-old full term, but not very preterm infants. Frontiers in Psychiatry, 8, 171. https://doi.org/10.3389/fpsyt.2017.00171

Provenzi, L., Guida, E., \& Montirosso, R. (2018). Preterm behavioral epigenetics: A systematic review. Neuroscience \& Biobehavioral Reviews, 84, 262-271. https://doi.org/10.1016/j.neubiorev.2017.08.020

Reynolds, L. C., Duncan, M. M., Smith, G. C., Mathur, A., Neil, J., Inder, T., \& Pineda, R. G. (2013). Parental presence and holding in the neonatal intensive care unit and associations with early neurobehavior. Fournal of Perinatology, 33(8), 636-641. https://doi.org/10.1038/jp.2013.4 
Risnes, K. R., Pape, K., Bjorngaard, J. H., Moster, D., Bracken, M. B., \& Romundstad, P. R. (2016). Premature adult death in individuals born preterm: A sibling comparison in a prospective nationwide follow-up study. PLoS One, 11(11), e0165051. https://doi.org/10.1371/journal.pone.0165051

Rosa, M. J., Lee, A., \& Wright, R. J. (2018). Evidence establishing a link between prenatal and early life stress and asthma development. Current Opinions in Allergy and Clinical Immunology, 18(2), 148-158. https://doi.org/10.1097/ACI.0000000000000421

Sanders, M. R., \& Hall, S. L. (2018). Trauma-informed care in the newborn intensive care unit: Promoting safety, security and connectedness. Fournal of Perinatology, 38, 3-10. https://doi .org/10.1038/jp.2017.124

Scatliffe, N., Casavant, S., Vittner, D., \& Cong, X. (2019). Oxytocin and early parent-infant interactions: A systematic review. International Fournal of Nursing Studies, 6(4), 445-453. https://doi .org/10.1016/j.ijnss.2019.09.009

Sikka, R., Morath, J. M., \& Leape, L. (2015). The Quadruple Aim: Care, health, cost and meaning in work. BM7 Quality and Safety, 24(10), 608-610. https://doi.org/10.1136/bmjqs-2015-004160

Simeoni, U., Armengaud, J.-B., Sideek, B., \& Tolsa, J.-F. (2018). Perinatal origins of adult disease. Neonatology, 113, 393-399. https://doi.org/10.1159/000487618

Stuebe, A. M., Jegier, B. J., Schwarz, E. B., Green, B. D., Reinhold, A. G., Colaizy, T. T., Bogen, D. L., Schaafer, A. J., Jegier, J. T., Green, N. S., \& Bartick, M. C. (2017). An online calculator to estimate the impact of changes in breastfeeding rates on population health and costs. Breastfeeding Medicine, 12(10), 645-658. https://doi.org/10.1089/bfm.2017.0083

Tikkanen, R., \& Abrams, M. K. (2020, January 30). U.S. bealth care from a global perspective, 2019: Higher spending, worse outcomes? https://www.commonwealthfund.org/publications/issue-briefs/2020/ jan/us-health-care-global-perspective-2019

Weber, A., \& Harrison, T. M. (2019). Reducing toxic stress in the NICU to improve infant outcomes. Nursing Outlook, 67(2), 169-189. https://doi.org/10.1016/j.outlook.2018.11.002

Weber, A. M., Harrison, T. M., \& Steward, D. K. (2018). Expanding regulation theory with oxytocin: A psychoneurobiological model for infant development. Nursing Research, 67(2), 133-145. https://doi.org/10.1097/NNR.0000000000000261 